\title{
The Politics of History in the Late Qing Era: William A. P. Martin and a History of International Law for China
}

\author{
Maria Adele Carrai \\ Assistant Professor of Global China Studies, New York University Shanghai, \\ Pudong, Shanghai, China \\ mac1o41@nyu.edu
}

Received:12 March 2019 | Revised: 18 November 2019 | Accepted: 30 January 2020 | Published online: 28 October 2020

\begin{abstract}
In the light of 19th-century attempts to universalize history and international law, the purpose of this article is to show how the theory of an Ancient Chinese international law matured and disseminated within one politics of history and helped generate another at the end of the Qing Dynasty. On the one hand, the middleman William Alexander Parsons Martin, who as part of his Christian mission and in order to make international law more acceptable to the Chinese, translated systematically international law into Chinese and attempted to universalize it by finding a protointernational law in Ancient China. On the other hand, Chinese scholars and officials sought to use Martin's theory to universalize Confucianism and rectify international law according to what they believed to be their own superior morality and history.
\end{abstract}

\section{Keywords}

international law - W. A. P. Martin - translation - Confucianism - history politics - China

\section{Introduction}

More than neutral descriptions of past events, histories of international law are often normative reconstructions responding to contemporary necessities. 
In the 19th century, Western powers' expansion forced them into contact with cultures and civilizations that shared little in common with Christianity. These encounters often prompted intellectuals, historians, and jurists in the Western world to rethink the historical and philosophical underpinnings of their normative constructs. Equally, intellectuals of countries whose normative orders had been forcefully shaken by Western powers' civilizing missions had to rethink their histories to make sense of and accommodate the fact that the international legal order was expanding at the expense of their own. Before the Opium Wars (1839-1860), the Qing normative order was grounded on the Tianxia worldview that implied the orchestrated and symbolic superiority of the Chinese emperors over the entire world. Yet despite its millenniumold civilization, China was seen by Westerners as part of a backward, sleepy Orient. After defeat in the Opium Wars, the Chinese Empire slowly entered the Western normative orbit. Translations into Chinese of modern international law had already begun, but it was still far from replacing China's vision of the world. For Chinese officials and scholars, international law belonged to inferior foreigners; reformists saw the practical value of Western learning and international law to deal with foreigners and ward off encroachment, but they believed in the superiority of their value system. ${ }^{1}$

As part of his Christian mission and in order to make international law more acceptable to the Chinese while encouraging China's recognition within the family of nations, the author of the first systematic translation into Chinese of international law, US missionary William Alexander Parsons Martin, attempted to universalize it by finding a proto-international law in Ancient China. This involved opposing most late-19th century histories of international law, which relegated the Chinese and the Orient to the margins of the 'family of nations' and their history. ${ }^{2}$ While much literature has discussed the introduction of

1 For instance the Self-Strengthening Movement of the 186os was formed by those Confucian intellectuals and officials like Feng Guifen 馮桂芬 (1809-1874), Prince Gong 恭亲王 (1833-1898), Zeng Guofang 曾國藩 (1811-1872), Li Hongzhang 李鴻章 (1823-1901), and Zuo Zongtang 左宗常 (1812-1885), who, while aware of and intrigued by Western science, were still dedicated to restoring imperial universal authority as the sole form of coherence and order. The restoration was led by the maxim of the famous official of the late Qing dynasty Zhang Zhidong (张之洞, 1837-1909): zhongxue weiti, xixue weiyong 中學為體, 西 學為用 (Traditional learning at the core, Western learning as an instrument). Discussed in Carrai, Maria Adele. Sovereignty in China. A Genealogy of a Concept since 1840 (Cambridge: Cambridge University Press, 2019), 58.

2 See Ruskola, Teemu. Legal Orientalism: China, the United States, and Modern Law (Cambridge: Harvard University Press, 2013), Chapter 1; Hsü, Immanuel C. China's Entrance into the Family of Nations: The Diplomatic Phase; 1858-1880 (Cambridge: Harvard University Press, 1968). 
western international law in China, ${ }^{3}$ this article, considering Chinese intellectuals' earliest analogies between the contemporary international situation and the Warring States period investigates how the theory of an Ancient Chinese international law was matured and disseminated within one politics of history and helped generate another at the end of the Qing Dynasty. On the one hand the middleman Martin wanted to universalize international law, seen as part of his religious toolkit, and make it acceptable to the Chinese. He wanted also to promote the emancipation in international society of the country that gave him, from 1869, a steady income and recognition. On the other hand, Chinese scholars and officials used Martin's theory to universalize Confucianism and rectify international law according to what they believed to be their own superior morality and history.

This article is composed of four sections. The first, The Emerging International Order and a Search for Analogies in China's Past, introduces the situation of China in the mid-19th century and Qing intellectuals' earliest analogies between the contemporary international situation and the Ancient Warring States period. These theories are the ones on which Martin's theory on the existence of international law in Ancient China relied. W.A.P. Martin as God's Agent to Open China to the Gospel and International Law presents Martin and his role in introducing religion blended with international law to China. The third part, Ancient China's International Law: Expanding International Law's Spatial and Temporal Dimensions, explores the genesis of Martin's theory about the existence of international law in Ancient China in light of debates at the Institut de Droit International and the reasons behind his attempts to universalize international law. The fourth section, Universalizing Confucianism through the History of International Law: A Chinese Response, looks at the debates that Martin's theory engendered within Chinese circles and the rationale of Chinese scholars in adopting it. The conclusion discusses the legacy of Martin's theory in light of current attempts at global histories of international law.

3 Svarverud, Rune. International Law as World Order in Late Imperial China: Translation, Reception and Discourse, 1847-1911 (Leiden: Brill, 2007); Hsü, China's Entrance 1968 (n. 2); Chiu, Hungdah. 'The Development of Chinese International Terms and the Problem of Their Translation into English'. Journal of Asian Studies 27(3) (1967), 485-501; Liu, Lydia. 'Legislating the Universal: The Circulation of International Law in the Nineteenth Century', in Tokens of Exchange: The Problem of Translation in Global Circulations, ed. Lydia Liu (Durham: Duke University Press, 1999), 127-164; Masini, Federico. The Formation of Modern Chinese Lexicon and Its Evolution toward a National Language: The Period from 1840 to 1898 (Berkeley: Project on Linguistic Analysis, 1993). 


\section{The Emerging International Order and a Search for Analogies in China's Past}

International law came to be conceived as 'universal' only in the 18th and 19th centuries, shifting from ius publicum europeaum to ius publicum universale. ${ }^{4}$ This new sense of universality justified and fueled colonial and imperial expansion in the 19th and 2oth century. ${ }^{5}$ The 19th century was the period in which modern international law's doctrine and practice largely developed, contributing to what has been defined as the birth of the modern world and international society. ${ }^{6}$ For 19th-century internationalists, such as Fedor Fedorovitch Martens, Henry Wheaton, François-André Isambert, Johann Kaspar Bluntschli, Augusto Pierantoni or Ernest Nys, who imagined a progressive history of international law governed by an evolutionary principle capable of naturally leading them toward a pragmatic, cosmopolitan, humanitarian, and liberal international law in the 2oth century, history was on their side. ${ }^{7}$ As European expansion reached its peak in the 188 os and 189 os, international lawyers such as Johann Kaspar Bluntschli, Pasquale Fiore and Charles Salomon, started to use the theory of 'degrees of civilization' to explore its legal, historical, and philosophical underpinning. ${ }^{8}$ Debates about the applicability of international law to 'the Orient' started to animate international lawyers' circles. According to the statutes of the Institute du Droit International, founded in 1873 , the only object of its attention was the 'civilized world', but the location of that world's

4 Vec, Miloš. 'Universalization, Particularization, and Discrimination. European Perspectives on a Cultural History of the 19th Century International Law'. InterDisciplines 3(2) (2012), 79101, 79, 82 .

5 Vec, Miloš. 'From the Congress of Vienna to the Paris Peace Treaties of 1919', in The Oxford Handbook of the History of International Law, eds. Bardo Fassbender and Anne Peters (Oxford: Oxford University Press, 2012), 654-678.

6 International law was institutionalized in the 19th century, as can be seen by the great powers' large production of treaties, protocols, and declarations, and international law doctrine emerged in the 19th century. See Macalister-Smith, Peter and Joachim Schwietzke. 'Bibliography of the Textbooks and Comprehensive Treaties in Positive International Law in the 19th Century'. Journal of the History of International Law 3(1) (2001), 75-142; Vec, 'From the Congress of Vienna' 2012 (n. 5), 674.

7 Vec, 'European Perspectives' 2012 (n. 4), 79; Koskenniemi, Martti. The Gentle Civilizer of Nations. The Rise and Fall of International Law 1870-1960 (Cambridge: Cambridge University Press, 2009), Chapter 2; Kennedy, David. 'International Law and the Nineteenth Century: History of an Illusion'. Nordic Journal of International Law 65(3-4) (1990), 385-420, 387.

8 Koskenniemi, Gentle Civilizer 2009 (n. 7), 103. 
borders came under scrutiny in the early decades of its existence and gave rise to the 'The Oriental Question'.

While European jurists already thought of international law as a universal order by the beginning of the 19th century, it was still far from the universally recognized system we know today. The Qing Empire, for instance, thought of itself as at the center of the universe, and together with its many vassals in East Asia ignored the existence of Wester international law. When the Western normative order encountered China, Western nations felt that 'the form of relationship specific to the Qing and imperial court was in some ways a transgression of an acceptable international norm', particularly its isolationism and Sinocentric, hierarchical world order. ${ }^{10}$ In fact, the diplomatic protocol of the tribute system that left European diplomats puzzled in the 18th and 19th centuries was no more fictional than that of the modern international law conceived

Anghie, Antony. Imperialism, Sovereignty and the Making of International Law (Cambridge: Cambridge University Press, 2005), 59-63; The question of international law's universality and applicability to the Orient was addressed at the 1875 Hague Conference, prompting further discussions in the following years. In 1877 the Institute du Droit International sent a questionnaire to experts on the region and its legal systems about the 'Applicability of the European Law of Nations to the Oriental Nations', asking whether, given 'such radical differences' between Oriental and European nations, it was possible to admit them to the general international law community. Annuaire de l'Institut de Droit International (Gand, 1877), 123, 141. Because the questions could not be answered in general terms, the questionnaire was reformulated in 1879 under the chairmanship of Sir Travis Twiss with the title 'The Oriental Question'. It addressed more technical aspects, such as the differences between 'less civilized' countries, and what kinds of reforms the Orient should implement to be civilized enough for admission. See Section H entitled 'Current Issues dealt from an international law perspective' in Annuaire de l'Institut de Droit International (Gand, 1878), 335. Within a few years, with the First Rapport of M. de Martens, admissibility came to depend on Western jurists' examination of East Asian countries' institutional and judicial reforms. See 'Examiner quelles réformes sont désirables dans les institutions judiciaires actuellement en vigueur dans les pays Orient, par rapport ause procès où est engagée une personne ressortissant à une puissance chrétienne d'Europe d'Amérique,' and 'Premier rapport de M. de. Martens. Comme il a été dit plus haut', at 13, 26 and 27; 'La réforme des institutions judiciaires en Orient,' in Annuaire de l'Institut de droit international (Gand, 1880-1882), 223, 229. In 1887 the question led to the creation of the Institute's twelfth commission, devoted to laying out the desirable reforms to the judicial institutions in Eastern countries. The commission was terminated in $1895^{-1896}$, after several states concluded bilateral treaties with Japan, negotiations had been conducted with other Oriental countries, and Japan had been admitted into the family of nations; it was noted that 'in these circumstances, our mandate has no longer reason to exist'. Annuaire de l'Institut de Droit International (Gand, 1895/96).

10 Hevia, James L. 'Sovereignty and Subject: Constituting Relationships of Power in Qing Guest Ritual', in Body, Subject and Power in China, eds. Angela Zito and Tani E. Barlow (Chicago: University of Chicago Press, 1994), 181-200, 182. 
of as a science."1 The need to include the 'otherness' of non-European countries in the ius publicum universale led to the creation of states of exceptions in which sovereignty was suspended. ${ }^{12}$ One of the clearest manifestations of this legal exceptionality here was the unequal treaties system, which brought China into the conceptual framework of international law, but as a semicivilized country that lacked full rights. ${ }^{13}$ In a sense international law, despite aspiring universality, has remained parochially European and a reflection of its politics.

As Europe's expansion peaked in the last two decades of the century, their 'uncivilized counterparts', as further discussed below, began seeking historical foundations in their own traditions to make sense of the new international order, facilitate their entrance into the family of nations, and ultimately rectify international law. At this point, amid Institute de Droit International debates about the possibility of applying customary international law to the Orient, Presbyterian missionary and long-time Institute member William Alexander Parsons Martin (Ding Weiliang 丁韙良, 1827-1916) ambitiously attempted to universalize it by expanding its origins to Ancient China. Indeed, he was the first historian of international law in China to explicitly posit, by manipulating original legal texts and constructing new historiographies, that in its antiquity China must have had a code of proto-international law. Martin with his translations created also a lexicon that would remain stable for over forty years; some

11 This was for instance the case of the famous British McCartney Embassy and its failure in 1793. Sponsored by the British East India Company, Lord George Macartney went to the Qing court as a representative of a sovereign nation, willing to perform the rituals required but without humiliating his country. The mission aimed to renegotiate British relations with China on new, more equal terms, establish permanent diplomatic missions, open up China to trade with Britain, and receive privileges to help rebalance Britain's trade deficit caused largely by tea imports. While Macartney did recognize the omnipotence of the emperor "in China" and had banners inscribed "The English Ambassador Bringing Tribute to the Emperor of China" in Chinese, when it came to ritual practices whose performance was not required in front of his own king, and that he felt would have implied recognition of the supreme authority of the Chinese emperor over her Britannic majesty, Macartney refused to kowtow, and this was tolerated by the Qing court. The letter Qianlong sent in response to George III was deemed disappointing as it basically rejected all the requests; Qianlong remarked that China possessed all things and "set no value on objects strange or ingenious and have no use for your country's manufactures." Britain felt scorned by both the failure of its envoys to expand trade in China according to the rules of international law and the unequal treatment it received. Carrai, Sovereignty in China 2019 (n. 1), 44-45.

12 Nuzzo, Luigi. Origini di una Scienza. Diritto Internazionale e Colonialismo nel XIX Secolo (Frankfurt am Main: Vittorio Klostermann, 2012).

13 Wang, Dong. China's Unequal Treaties: Narrating National History (New York: Lexington Books, 2008), 25 . 
of it is still used now in Chinese legal language. ${ }^{14}$ Although his contribution to the Institute was modest, his theory not only had huge repercussions among China's newly trained jurists, but also has a strong legacy in today's histories of international law as Chinese jurists and international lawyers continue to refer to his theory about the existence of an Ancient Chinese international law.

Before China was accepted into the family of nations, it managed its foreign relations through the so-called tribute system. ${ }^{15}$ Although the analytical framework provided by this system, chaogong tixi 朝貢體系, is too simplistic and it does not do justice to the complex and differentiated set of rules regulating relations between the Middle Kingdom and its neighboring countries, it does highlight differences between the pre-2oth century China normative system and that of the West. Before Martin's systematic translation, passages of codes of international law were introduced into China during the First Opium War (1839-1842), when Lin Zexu (林則徐), the Guangdong governor appointed by the Qing Government to negotiate opium-trade-related controversies with Britain, asked imperial interpreter Yuan Dehui (袁德輝) to translate passages from Emer de Vattel's Le droit des gens (1758). Yuan's final version, Geguo lüli 《各國律例》, in which de Vattel's name is translated as Hua Daer 滑達爾, was published in 1847 in Wei Yuan's sixty-chapter geographical work An Illustrated Gazetteer of Maritime Countries (Haiguo Tuzhi《海國圖志》).16

14 Masini, Modern Chinese Lexicon 1993 (n. 3); Svarverud, Rune. International Law as World Order in Late Imperial China: Translation, Reception and Discourse, 1847-1911 (Leiden: Brill, 2007).

15 Although it has been heavily criticized and is in many ways outdated today, an important study of the Chinese tribute system was that of historian of China John K. Fairbank, whose scholarship has strongly influenced studies of Chinese foreign relations. See Fairbank, John K. and Ssu-yü Têng. 'On the Ch'ing Tributary System'. Harvard Journal of Asiatic Studies 6(2), 135-246; Fairbank, John K., ed. The Chinese World Order, Traditional China's Foreign Relations. (Cambridge: Harvard University Press, 1968), 196. See also Rossabi, Morris. China among Equals: The Middle Kingdom and its Neighbors (Berkeley: University of California Press, 1982); Mancall, Mark. China at the Center: 300 Years of Foreign Policy (New York: Free Press, 1984); For more recent and discursive interpretations of the tribute system, see Kang, David C. East Asia before the West: Five Centuries of Trade and Tribute (New York: Columbia University Press, 2010); Wright, David Curtis. From War to Diplomatic Parity in Eleventh-Century China, Sung's Foreign Relations with Kitan Liao (Leiden: Brill, 2005); Suzuki, Shogo. Civilization and Empire: China and Japan's Encounter with European International Society (Abingdon: Routledge, 20o9); Hamashita, Takeshi. China, East Asia and the Global Economy: Regional and Historical Perspectives (Abingdon: Routledge, 2008).

16 Yuan's translation was based on Joseph Chitty's 1833 English translation of de Vattel as Law of Nations, or Principles of the Law of Nature, Applied to the Conduct of and Affairs Nations and Sovereigns. Lam Hok-Chung 林學忠. Cong wanguo gongfa dao gongfa waijiao 《從萬國公法到公法外交》[From the Law of Nations to International Diplomacy] 
It was only after the Second Opium War (1856-1860), in 1864, that Martin's more comprehensive translation of works of international law was introduced. At this point Chinese diplomats started to adopt its conceptual and linguistic framework as a reference. ${ }^{17}$

Martin's translation was prompted by the defeats in the two Opium Wars, after which Qing intellectuals gradually realized that they were facing issues that could not be properly addressed through the more traditional conceptual and normative system. The world had changed, and the Qing had to find new words and theoretical framework to deal with it. This is apparent in the work of Qing intellectual and geographer Xu Jiyu (徐繼蕃) (1795-1873), a highranking official. ${ }^{18}$ Appointed to the coastal prefecture of Fujian, he came in direct contact with foreigners and witnessed the defeat of the first Opium War firsthand. In his A Short Account of the Maritime Circuit (Yinghuan zhilüe, 《汶 環志略》), written in 1847 but not circulated because of conservative opposition until the 186os, Xu provided a new geography of the world, in which China itself is re-dimensioned according to Western measurements and geographical representations. While in traditional maps China was represented as the world and at the center of universe, with no clear defined boundaries that separated it from the rest of the world, in the map of Xu Jiyu there are four continents and China is part of the Asian continent, although China rules supreme over its dependencies within that continent. ${ }^{19}$ Moreover, Xu was the first scholar to initiate analogies between the contemporary international system and the Warring States period ( $475^{-249} \mathrm{BC}$ ), giving rise to what has been defined as the 'Spring and Autumn, Warring States theory' (Chunqiu Zhanguo Lun《春秋戰 國論》). According to the theory the current state of international relations and

(Shanghai: Shanghai Guji Chubanshe, 2009), 44-48. The translation is also discussed in Hsü, China's Entrance 196o (n. 2), 123-125; Liu, Lydia. The Clash of Empires: The Invention of China in Modern World Making (Cambridge: Harvard University Press, 2004), 118-119; Masini, Modern Chinese Lexicon 1993 (n. 3), 21-28; Svarverud, International Law as World Order 2007 (n. 14), 75-87.

17 Wheaton, Henry and William A. P. Martin. Wan guo gong fa《萬國公法》(Taibei: Zhongguo guo ji fa xue hui, 1998). Before Yuan Dehui's translation of Vattel, the missionary Martino Martini (1641-1661) translated passages from the international law work of the Salamanca School renown jurist Francisco Suarez (1548-1617), and in 1689 the missionaries Tomas Pereira (1645-1703) and Jean Francois Gerbillon (1654-1707) served as interpreters and negotiators for the China-Russia Treaty of Nerchinsk, pointing out the usefulness of international law. See Sebes, Joseph. The Jesuits and the Sino-Russian Treaty of Nerchinsk (1689): The Diary of Thomas Pereira (Rome: Institutum Historicum SI, 1961).

18 See Lutz, Jessie G. 'China's View of the West, A Comparison of the Historical Geographies of Wei Yuan and Xu Jiyu'. Social Sciences and Mission 25(1-2) (2012), 35-52.

19 Drake, Fred. China Charts the World: Hsu Chi-Yu and His Geography of 1848 (Cambridge Harvard University Press, 1975), 68. 
situation were analogous to the one in the Spring and Autumns Warring States Period, the era of division in ancient China characterized by the existence of various states that were at war before the Qin state conquered them all in 221 BC and reunited the territory under the Qin Dynasty (221 to 206 BC). ${ }^{20}$

The Eastern Zhou (770-256 BC), that comprises both the Spring and Autumns (771-476 BC) and the Warring States Period (475-221 BC), is the period in which the Zhou royal authority over the various feudal states started to erode. In the Warring States period, in particular, the various states of Qin, Chu, Zhao, Wei, Han, Yan, and Qi declared independence from the Zhou Dynasty and competed for power. In Chinese dynastic tradition the Eastern Zhou period is a significant one. Not only it was one of the key moments of disunity and fights for hegemony among the different states before the establishment of the first unified and long-lasting Chinese Empire in $221 \mathrm{BC}$. It was also a time in which many great philosophical schools emerged together with governmental structure and tenants of political culture. The crucial issue of rulership gave rise to the so-called Hundred Schools of Thoughts (including Confucianism, Legalism, Taoism, Mohism, the School of Yin-yang, the Logicians etc.). In the traditional political culture of China that favors the unity of the empire, it was not considered as a positive example. However, in the 19th and 2oth centuries its legacy has generated much interest among political figures and academics as it was used as a repository of strategies and multi-state experiences for finding both analogies for the new international situation and remedies to the turmoil of the 19th and 2oth centuries. ${ }^{21}$

$\mathrm{Xu}$ compared European countries and their relations to the Warring States period; specifically, Britain, Russia and France became identified with the

20 Among the scholars that have discussed the Qing intellectuals that have created a parallel between the international situation of the late 19th century and the Warring States Period see Zeng Tao 曾涛. 'Jindai Zhongguo de guojifa fuhui lun 近代中国的 国际法附会论'. Fashi xue kan 法史学刊 (2007) available at: http://cesl.cupl.edu.cn/ upload/201103224076038.pdf; (last accessed 14 September 2020) Zhang Weiming 张卫明. 'Yangwu shiqi guoren dui jindai guji jushi yu guojifa de bifu 洋务时期 国人对近代国际局势与国际公法的比附? Shijie Jingji yu Zhengzhi 世界经济 与政治 6 (2010), 81-83; Xiao Yonghong 萧永宏. 'Lun Yangwu shiqi Zhongguoren de guoji zhengzhi guannian 论洋务时期中国人的国际政治观念: Xueshu yuekan 学术月刊12 (1997), 83-9o; Wang Ermin 王尔敏. Zhongguo Jindai sixiang shi lun 《中国近代思想史论》(Beijing: Shehui kexue wexian chuban, 2003); Tian Tao 田涛. Guojifa shuru wanqing Zhongguo《国际法输入与晚清中 国〉) (Jinan: Jinan chubanshe, 2001).

21 Pines, Yuri. Envisioning Eternal Empire, Chinese Political Thought of the Warring States Era (Honolulu: University of Hawai'i Press, 2009), 1-4, 219-222. 
some of the Warring States..$^{22}$ By providing a more realistic account of the contemporary world and dividing it into states, Xu's work was not only the first to create an analogy with Chinese history that would become essential for Qing intellectuals and for Martin; it also had implications for the perceived primacy of Chinese civilization. ${ }^{23}$ Although Europe was geographically far from China and not transformed by Chinese rituals and music, Xu wrote, its civilization was still admirable and should have almost equal status with the Middle Kingdom., Zhongguo 中国, the old name for China as it was considered the kingdom at the center of the world, hence, according to the Chinese cosmology, superior to other kingdoms. ${ }^{24}$ Yet while the secular model of sovereign states with its ideology of the balance of power and equality may resemble China's ancient Warring States, for $\mathrm{Xu}$ it was not a valid alternative to the Chinese sacral imperial order; it was merely important to gain knowledge of it in order to become stronger and thus resist Western incursions. Nevertheless, by presenting a new image of the world, in which China was increasingly individualized as a sovereign state, the geographies Xu considered indirectly constituted a first autochthonous challenge to the idea of cosmic kinship, which was already threatened by pressures from foreign powers such as the unequal treaties. After the Second Opium War, the general inertia with which his works were received at court was replaced by a new attitude that prompted Martin's translations and a different approach to the West. ${ }^{25}$

Another important intellectual to further develop the analogy with the Warring States was Feng Guifen, who greatly contributed to the philosophy of the Self-Strengthening Movement (1861-72). In his 1861 Petitions from Jiaobinlu 《校邠盧抗議》, he wrote:

Are not today's overseas barbarians and the countries of the Spring and Autumn Period in a similar situation and is not the context the same? When the level of power is high, it must be justified. [...] In the same way as in the Warring States period [in the current situation] the great

22 “法国, 英国, 俄罗斯 ‘比权量力, 不过齐秦普, 楚相为敌已耳“葡萄牙则’不 过滕”, discussed in Zeng Tao 曾涛 , 'Jindai Zhongguo de guojifa fuhui lun 近代中国的 国际法附会论' (2007); Zhang Weiming 张卫明. 'Yangwu shiqi guoren dui jindai guji jushi yu guojifa de bifu 洋务时期国人对近代国际局势与国际公法的比附. Shijie Jingji yu Zhengzhi 世界经济与政治 6 (2010), 81-83.

23 Drake, China Charts the World 1975 (n. 19), 149.

24 For instance, the Prussian king is praised because he is able to connect the people to his government, and Germany is deemed to be the China of Europe not only for its geographical centrality but its sophisticated culture. Ibid., 145-146.

25 Schoppa, R. Keith. Revolution and Its Past:Identities and Change in Modern Chinese History (Upper Saddle River: Prentice Hall, 3rd ed. 2011), 92. 
country invades the small, the strong buries the weak, but there must be an excuse regardless of one's beliefs and it does not matter if it's unreasonable. ${ }^{26}$

This analogy had significant repercussions on Chinese scholars in the late Qing period. Using the analogy with the multi-states system of the Spring and Autumn and the Warring States periods, helped Chinese establishing a broader understanding of the world that by the end of the 19th century was characterized by a multinational system. By suggesting that China was not a central kingdom but a country among equal countries, it indirectly helped abolish Chinese centralism and bring the country into the new global context. It had also important repercussions on China's modern diplomatic thinking and practice, because it called for referencing ancient experience, especially in relation to the way the Western powers maintained international peace. ${ }^{27}$ Moreover, it was on the basis of this analogy and reinterpretation of history that Martin's widely disseminated theory of the existence of international law in Ancient China would form.

\section{W. A. P. Martin as God's Agent to Open China to the Gospel and International Law}

China's defeat in the Second Opium War, in 186o, made manifest its incapacity to resist Western powers on its territory, either by force or conciliation. The 1858 Tianjin Treaty and the 186 o Beijing Convention put an end to the war and brought to maturity the unequal treaties system, which legalized Western encroachment of Chinese sovereignty. ${ }^{28}$ China's weakness, the growing inter-

26 “今海外诸夷,一春秋时之列国也, 不特形势同, 即风气亦相近焉。势力相高而 言必称理, 谲诈相尚而口必道信, 两军交战, 不废通使, 一旦渝平, 居然与 国。亦复大侵小、强陵弱, 而必有其藉口之端, 不闻有不论理、不论信, 如 战国时事者." Feng Guifen 冯桂芬, Jiaobin lu Kangyi 校邠庐抗议, Volume 2, available at: https://ctext.org/wiki.pl?if=gb\&res $=551265 \&$ searchu= $\% \mathrm{E} 4 \% \mathrm{BB} \% 8 \mathrm{~A} \% \mathrm{E} 6 \% \mathrm{~B} 5 \% \mathrm{~B} 7 \% \mathrm{E}$ 5\%A4\%96\&remap=gb.

27 Wang Ermin王尔敏. Zhongguo Jindai sixiang shi lun 《中国近代思想史论》 (Beijing: Shehui kexue wenxian chuban, 2003), 156-166.

28 While the 1942 Treaty of Nanjing had opened China only to Britain, France, and the US, the Treaty of Tianjin and the Convention of Beijing opened it to most Western powers: Russia, Belgium, Germany, Portugal, Denmark, the Netherlands, Spain, Italy, Austria-Hungary, Japan, Peru and Brazil: France (Treaty of Tianjin 1858, Convention of Beijing 1860), United States of America (Treaty of Tianjin 1858, Convention of Beijing 1868), Russia (Treaty of Tianjin 1858, Convention of Beijing 1860), Germany (Treaty of Tianjin 1861), 
ference of Western powers, and the general internal discontent that exploded in the Taiping Rebellion (1850-1864) prompted a national sense of crisis among Chinese intellectuals, which encouraged a renewed interest in Western technology and science, seen as indispensable tools for recovering strength. Among the ruling class the change of attitude toward Western institutions and knowledge was sealed by the New Foreign Policy memorial submitted in January 1861 by three figures: Prince Gong, imperial commissioner and brother of the Emperor Xianfeng; Guiliang, grand secretary; and Wenxiang, assistant secretary of the Board of Revenue. The first of the six regulations it contained established a new foreign affairs body, the Zongli Waiguo shiwu Yamen 總理 外國事務衙門, launched in March 1861. ${ }^{29}$ The fifth regulation ruled that delegates from Canton and Shanghai, who understood written and spoken foreign languages, must be sent to Beijing for consultation in what would later be known as the Tongwenguan 同文館, an institute dedicated to Western learning and the translation of Western texts founded in Beijing in $1862 .{ }^{30}$

It is within the Tongwenguan that Martin produced the first systematic translation of international law into Chinese. ${ }^{31}$ It was printed by the Chinese

Belgium (Treaty of Beijing 1865), Denmark (Treaty of Beijing 1863), Holland (Treaty of Tianjin 1863), Portugal (Treaty of Tianjin 1862), Spain (Treaty of Tianjin 1864), Italy (Treaty of Tianjin 1866), Austria-Hungary (Treaty of Beijing 1869), Japan (Treaty of Tianjin 1871), Peru (Treaty of Tianjin 1874). Treaty, Convention, etc. between China and Foreign States, Vol. 1, 2 (Shanghai: Department of the Inspector General of the Customs, 1917).

29 New Foreign Policy memorial of 1861 in John K. Fairbank and Ssu-yü Têng, China's Response to the West: A Documentary Survey 1839-1923, with E-Tu Zen Su, Chao Yingfang \& others, Cambridge, Mass.: Harvard University Press (New York: Athenum, 1965), 47-49, 48-49.

30 See translation of New Foreign Policy memorial of 1861 in ibid. 48.

31 Martin was born in 1827 in Livonia, Indiana, and completed his theological studies at the McCormick Theological Seminary (later called the New Albany Theological Seminary) in 1849. He was appointed a missionary to China that same year and arrived in Ningbo with his wife in April 185o. In 1865 the Chinese government invited Martin to teach English two hours a day in the Tongwenguan. In 1867, as the language school was being reorganized and gradually expanded around a curriculum that included multiple aspects of Western learning, he was appointed professor of international law and political economy. He then took a second short but intense furlough in the US: 'I committed the interests of the mission to other hands and went for special studies prior to entering on the duties of my chair.; Martin, William A. P. A Cycle of Cathay: Or, China, South and North, with Personal Reminiscences (New York: Fleming H. Revell, 190o), 241. He obtained a Doctor of Law from New York University (to be followed up by one from Princeton University in 1899) and came into contact with influential international law professor Theodore Dwight Woolsey at Yale University through his sons Pascal and Winfred, who were students there. Martin would translate Woolsey's 1860 book Introduction to the Study of International Law: Designed as an Aid in Teaching, and in Historical Studies into Chinese as Gongfa bianlan 《公法便览》; after its publication in 1875 it became the central text 
central government and widely circulated among modern Chinese politicians, diplomats, and intellectuals. No international law expert, Martin was a Presbyterian missionary from Indiana sent to Ningbo in 1849 who became acquainted with the subject as an interpreter for the US legation to the 1858 Tianjin Treaty negotiations. ${ }^{32}$ Missionaries due to their knowledge of local languages and culture, they were often invited by merchants and diplomats to serve in communication and business. In the 19th and early 2oth centuries, among Westerners in China, it was missionaries that were the most numerous and invested. Committed to learning the Chinese culture and language, they view Chinese people very differently from merchants and diplomats. They emphasized Chinese people 'welfare' and believed in their gradual conversion to Christianity. ${ }^{33}$ Martin developed the idea of translating international law into Chinese and creating a high-grade school to train Chinese Christians in Western learning, in the belief such a translation would help expose the 'superiority of Christian Civilization' and ultimately spread Christianity in China. ${ }^{34}$ Having

for training students at the Tongwen Guan. See Svarverud, International Law as World Order 2007 (n. 14), 96; Martin, Cycle of Cathay 1900 (n. 31), 235. For his achievements and aid to the Chinese government, in 1885 Martin was given the rank of Mandarin of Third Class, and in 1898, when the government founded the Imperial University of China (later Peking University), Guangxu Emperor made him its president and ranked him Mandarin of Second Class. The Boxer Rebellion of 1900 disrupted the institution's development and Martin's presidency, and he returned to the US for almost a year. Toward the end of 1901 the governor general, Zhang Zhidong, appointed him president of a new government university at Wuchang for a three-year term, but on arrival Martin found that the university was not yet established and instead spent 1902 to 1905 as president of the Hubei Mandarin Institute (Hubei Shixueyuan 湖北仕學院) and the Hubei Jimei Xuetang (湖 北濟美学堂), teaching international law, diplomacy and geography to Zhang Zhidong's officials. Ding Weiliang 丁韪良, Bangjiao Tiyao 《邦交提要》 (廣學會清光緒三十 年刻本, 1904), 2; Martin, William A. P. The Awakening of China (New York: Doubleday, Page \& Company, 1910), 230. After his three-year mandate he returned briefly to the US and was appointed honorary member of the North China Mission; he returned to Beijing in 1905 and died there in 1916. Wang Lixin 王立新, Meiguo Chuanjiao shi yu wan qing zhongguo xiandaihua 《美国传教士与晚清中国现代化》 (天津: 天津人民出版社, 1997): Wang Weijian 王维俭, 'Dingzheng ruogan zhongwai ci shu zhong Ding Weiliang ci mu sheji de shishi 订正若干中外词书中“韪良'词目涉及的史实' Zhongshan daxue Xuebao 中山大学学报 2 (1987), 68-76.

32 Martin applied for the post with the US delegation. See Martin, Cycle of Cathay 1900 (n. 31), 147.

33 Wang, Jing. 'The Image of China Shaped by American Missionaries and Its Impact on the Early Twentieth Century'. Journal of Cultural Interaction in East Asia 6 (2015), 31-45.

34 Covell, Ralph R. W. A. P. Martin, Pioneer of Progress in China (Christian University Press, 1978), 133; Harris, Paul. 'Cultural Imperialism and American Protestant Missionaries: Collaboration and Dependency in Mid-Nineteenth-Century China'. Pacific Historical Review 6o (1991), 309-338. 
come up with the idea during a 1859-1862 furlough, he initially considered de Vattel as a starting point; when he visited Shanghai in 1862, John E. Ward, US minister to China during the 186o Dagu Crisis, recommended Henry Wheaton as 'more modern and equally authoritative. ${ }^{35}$ With the help of some Chinese translators and the support of new US Minister to China Anson Burlingame, new British Inspector-General of China's Imperial Maritime Custom Service Robert Hart, and the Zongli Yamen, he completed the translation of Wheaton's 1836 book Elements of International Law as Wanguo Gongfa in $1864 .{ }^{36}$ Overall, Wanguo Gongfa is a very meaningful book, not only because it is the first systematic translation of international law, but it also meant the approval and gradual acceptance of a different world order.

Scholars have given various motivations for Martin's translation of the book. For some, Martin, Burlingame, and Hart supported the translation to open up the closed-door policy of the Qing government and bring its diplomacy within the orbit of Western international law, its practices, and ultimately its religious and normative underpinnings: Their mission thus reflected a civilizing mission to conquer China religiously and normatively. ${ }^{37}$ This reflects also Latourette's reading of missionaries 'work', for whom 'the primary motives back of the missionary movement were unselfish. Selfish ones were undoubtedly there: the increase of the glory and power of a Western nation or of an order or a society, the desire for personal renown, and the urge to adventure. Missionaries were pioneers and were impelled in part, as are all pioneers, by a passion for achievement in a fresh environment. In the great majority of missionaries, however, the dominant motive had little of self: it was a feeling of obligation to share with others a message, a salvation, a way of life which the missionary believed of supreme importance. ${ }^{38}$ For others, Martin's work was beneficial for China but simultaneously helped justify and legalize Western powers' invasion. ${ }^{39}$ Other scholars, such as Norma J. Burns, Lin Zhiping and Wu Sumin, believe that the main motivation was the fact that the translation would be useful to

35 Martin, Cycle of Cathay 1900 (n. 31), 221-222.

36 Ibid., 234-235; The translation was divided into four chapters (1. 釋公法之義, 明其本 源, 題其大旨, 2. 論諸國自然之權, 3. 論諸國平時往來之權, 4. 論交戰條規).

37 Wang Weijian 王伟检. 'Pu dan dazhankou chuanbo shijian he xifang guojifa chuanru zhongguo 普丹大沾口船舶事件和西方国际法传入中国': Xueshu yanjiu 学术研究5 (1985), 84-9o.

38 Latourette, Kenneth S. A History of Christian Missions in China (London: Society for Promoting Christian Knowledge, 1929), 824.

39 Zhang Jingcao 张劲草, Qiu Zaijue 邱在珏. 'Lun guojifa zhi chuanru Zhongguo 论国际 法之传入中国, Hebei Daxue Xuebao 河北大学学报 2 (1984), 126-133. 
China for its diplomatic interactions after the Second Opium War. ${ }^{40}$ For Tian Tao, Zhang Yanqing, and Gao Liping, Martin sought to promote colonialism, but also, more importantly, to serve his religious commitment to introduce a standard of justice grounded on the Christian God. For them, Martin was devoted to promoting China's acceptance of such standards but also to ensure that it was accepted into the family of nations. ${ }^{41}$

Martin's motivations, of course, were multiple. While his first motivation was to spread Christianity and supporting his evangelic work, indeed, his motivations intersected and sometimes even clashed with each other, reflecting the complex personality and delicate position of a mediator between two world orders. As Fu Deyuan has observed, Martin's translation had to do with advancing his own career as well as spreading Christianity, and secondly, allowing Chinese to understand international law for use in diplomatic affairs. ${ }^{42}$ China was the country that gave Martin much higher salary than the Mission and prestigious position, especially from 1869, when he resigned from the Presbyterian mission and became a Chinese government employee at the newly established Tongwenguan. The latter consulted him on questions of international law when political and legal disputes with European powers arose. ${ }^{43} \mathrm{He}$ had officially become an agent of God's providence in opening China to international law - with a salary almost ten times his previous one. He justified his new position thus: 'The college is secular, and it cannot be otherwise, but in my hands by the blessing of God it will be at least less antiChristian than it would be otherwise. ${ }^{44}$

40 Lin Zhiping 林治平, Kexue yu jiu en-Jidujiao yu huaren xiandaihua meijie renwu de yanjiu 《科學與救恩: 基督教與華人現代化媒介人物的研究》(Taibei: Taibei Yuzhou guang chubanshe 1993), 251-252; Wu Suming 吴素敏, Ding Weiliang zhi yanjiu (18271916) 《丁趛良之研究 (1827-1916)》 (Taibei Donghai Daxue Shuoshi lunwen, 1987) 158159; Burns, Norma J. W. A. P. Martin and the Westernization of China (Indiana University, MA Thesis Mar. 1954), 218. See also Fu Deyuan, 傅德元, 'Ding Weiliang wanguo gong fa fanyi lanben ji yitu xin tan 丁韪良 ‘万国公法翻译蓝本及意图新探. Anhui Shixue 安 徽史学 1 (2008), 52-53.

41 Tian Tao 田涛. 'Wan qing guojifa shu shu lun 晚清国际法输述论, Tianjin shehui kexue 天津社会科学 6 (1999), 99-103; Tian Tao 田涛, Guojifa shuru wan qing Zhongguo 《国 际法输入与晚清中国》 2001, 49-50.

42 Fu Deyuan. 傅德元, 'Ding Weiliang wanguo gong fa fanyi lanben ji yitu xin tan 丁韪良 '万国公法翻译蓝本及意图新探, Anhui Shixue 安徽史学 1 (2008), 45-53, 52-53.

43 'Rev. W. A. P. Martin, D. D., of China.' The Missionary Review of the World (March 1917), 198; Appendix F, Dr. W. A. P. Martin - Its First President ‘The Tongwen College', in H.B. Morse, The International Relations of the Chinese Empire Vol. 3 (New York: Longmans, Green \& Co., 1910).

44 'Peking, Martin to Board, 169, December 1, 1869', in Presbyterian Church in the U.S.A. Board of Foreign Missions Correspondence and Reports, 1833-1911. With Martin as president the 
Reflecting his evangelical work, there is no doubt that for Martin Wanguo Gongfa was part of his Christian mission in China: 'I was led to undertake it ... providentially ... as a work which might bring this atheistic government to the recognition of God and his Eternal Justice and perhaps impart to them something of the spirit of Christianity'. ${ }^{45} \mathrm{He}$ justified the translation in the English preface, saying that to international law's 'fundamental principle, the Chinese mind is prepared to yield a ready assent', that it was inscribed in human hearts and was thus universal. ${ }^{46}$ Martin's view of international law as a complementary tool for recruiting new Christians could already be seen in 1857, when, due to his Chinese language skills, he was called on to assist Rev. Dr. Samuel Wells Williams as interpreter and adviser to US Minister William B. Reed. Justifying his decision to accept to the Presbyterian Church, he wrote that in helping with the treaty he especially hoped to promote liberty of conscience and missionary labor and to secure a missionary location in Beijing, as he believed a city residence would be useful to spread the faith. ${ }^{47}$ Missionaries were not allowed in the capital, and previous years had seen debates in missionary circles on how to revise existing treaties to extract more privileges and Beijing access. ${ }^{48}$ While Martin thought that 'in the dispensation of Providence it seems to be necessary that these conceited Asiatics should be humbled by the Sword,

Tongwen Guan became an important center for training top officials in the art of diplomacy, history, and international law. Many of its alumni were dispatched as interpreters and ministers, such as Ching Chang, as minister to France; 'Appendix F, Dr. W. A. P. Martin Its First President "The Tongwen College", in Hosea B. Morse, The International Relations of the Chinese Empire, Vol. 3 (London: Longmans, Green \& Co., 1910), 471-472; Martin, William A. P. The Lore of Cathay, or, the Intellect of China (New York: F. H. Revell, 19o1). During Martin's presidency, the school translated several international law books, including Charles de Martens' Guide Diplomatique as Xingyao Zhigang 星轺指掌; Johann Caspar Bluntschli's Das moderne Völkerrecht der civilisirten Staten als Rechtsbuch dargestellt as Gongfa huitong 《公法汇通》 (1879); the Institute de Droit International's manual on rules on war, Les Lois de la Guerre sur Terre, as Ludi zhanli xinxuan 《陆地 战例新选》 (1882); and William Edward Halland's A Treatise on International Law as Gongfaxinbian 《公法新编》 (1903).

45 'CL VII, Martin to the Board, n. 44, October 1, 1863' in Presbyterian Church in the U.S.A. Board of Foreign Missions Correspondence and Reports, 1833-1911.

46 Martin, William A. P. Wan guo gong fa 《万国公法》 (Taibei: Zhongguo guo ji fa xue hui, 1998), 1.

47 'W. A. P. Martin, Shanghai June 3, 1859' and 'W. A. P. Martin, June 18, 1858', in Presbyterian Church in the U.S.A. Board of Foreign Missions Correspondence and Reports, 1833-1911; see also W. A. P. Martin? Papers, 1869-1887, Record Group 357, Mr. Ward's Embassy; see also CL IV Ningbo, Martin to Board, $45 \cdot 1854$ (letter that accompanied the annual report), Presbyterian Church in the U.S.A. Board of Foreign Missions Correspondence and Reports, 1833-1911.

48 Covell, W. A. P. Martin 1978 (n. 34), 240. 
before they are exalted by the Gospel' and that force instead of religion or international law was the only way to deal with 'perfidious' Chinese, he also partly understood Chinese resentment toward the missionaries, who were seen as facilitators of opium smuggling. A critic of opium, Martin remarked that if the early missionaries had done more in pointing out the enormity of the opium evil, a curse might have been averted from China and a mountainous obstacle out of the way of Christian Mission'49 While in drafting the Treaty of $185^{8}$, Reed was 'not disposed' to include the article regarding religious freedom, it was the missionary interpreters Williams and Martin who 'persisted' in having the clause included and eventually the paragraph on religious freedom was included. Article 29 in the American Treaty of Tianjin granted religious liberty to all Christians and opened the door for missionaries to enter China in droves. ${ }^{50}$ The foreign powers were granted most-favored-nation clauses, and helped the missionary cause by opening China not only to further trade but to the Gospel and 'civilization', which, Martin increasingly thought, included international law. ${ }^{51}$ Martin thus became not only an agent of God, but of the broader civilizing mission of the West that included the universalization of international law, seen as instrumental to his evangelical mission. 'All barriers are withdrawn', he wrote to the church after the Treaty's negotiations' success. 'The chief nations of the earth should thus conspire to advance the cause of Christ is a glorious harbinger of his universal sway.'52 For Martin international

49 The first quotation is from an unpublished work at the Presbyterian Historical Society, Two American Embassies, I, 111, I, 32. CL IV, NING Bo, Martin to the Board, m. 86, May 22, 1859 .

50 Latourette, Kenneth S. A History of Christian Missions in China (London: Society for Promoting Christian Knowledge, 1929), 275. The treaty would be signed by the US, Russia, England, and France, who each acquired a new right to station legations in Beijing. It also opened up more ports to trade, and allowed foreigners to travel, trade, and proselytize in China's interior. Moreover, it stipulated: 'The principles of the Christian religion, as professed by the Protestant and Roman Catholic churches, are recognized as teaching men to do good, and to do to others as they would have others do to them. Hereafter those who quietly profess and teach these doctrines shall not be harassed or persecuted on account of their faith. Any person, whether citizen of the United States or Chinese convert, who, according to these tenets, peaceably teach and practice the principles of Christianity, shall in no case be interfered with or molested. 'The Treaty Of Tianjin (Tien-Tsin), 1858', in Department of the Inspector General of the Customs, Treaty, Convention, etc. between China and Foreign States, Vols. 1-2 (Shanghai, 1917); see also Martin, Two American Embassies 1859 (n. 49), I, 197.

51 'Ningbo, E. B. Inslee to the Board, July 30, 1858', in Presbyterian Church in the U.S.A. Board of Foreign Missions Correspondence and Reports, 1833-1911.

52 'Ningbo, Martin to Board, n. 156, July 9, 1858'1858', in Presbyterian Church in the U.S.A. Board of Foreign Missions Correspondence and Reports, 1833-1911. 
law was a universalization tool that presupposed the existence of God. In order to find commensurability between China's system and international law, in his English preface to Wanguo Gongfa, Martin moralized and universalized the latter on the basis of a natural law inscribed by God in the heart of every human. Moreover, the translated title itself was an effort to show China that international law was not simply a regional (Western) rule system but had universal value. He translated the title of Wheaton's Elements of International Law into 'the law of the nations', implying its universal applicability to the international community. Wanguo Gongfa was thus accompanied by universalization both in its title and in its moralization in terms of natural law, understood as a supranational restraint over states' ambitions and egotistic aspirations. ${ }^{53}$

Martin's approach to translation was far from rigid. Just as he believed it was important not just to translate the Bible into the local language, but to adapt and stretch or select its meanings to make it more acceptable and meaningful within local cultural heritage and symbols, Martin changed and manipulated Wheaton and the other texts to make them more palatable and comprehensible to Chinese. He thought that changing meaning was necessary to adapt the texts to the wants of China in its new foreign relations. ${ }^{54}$ As Yang Zhuo has argued, this attitude led Martin to a real 're-writing of the text[s]' (gaixie 改寫). ${ }^{55}$ A comparison of the original Wheaton text and Wanguo Gongfa makes clear that Martin rewrote and shortened parts. James Li has described how the intent to universalize is obvious in various passages: Martin used a semi-classical linguistic style to appeal to Chinese literati, but also paraphrased and interpreted Wheaton according to his own vision and politics of international law's history, especially when he wanted to convey the discipline's universality. ${ }^{56}$ One salient example of Martin's changes, as discussed by Immanuel C.Y. Hsu, Yang Zhuo, and Li, comes when Wheaton, after quoting Grotius, Bynkershoek, Leibnitz, and Montesquieu, writes: 'There is then, according to these writers, no universal law of nations, such as Cicero describes in his treatise $D e$

53 According to Carl Schmitt, when the state becomes the justus hostis and the equality of states replaces the religious authority of the pope, each state is the judge of its own affairs, and is bound only by its own treaties and its own interpretations of them. Because each is as sovereign as the other, each has the same jus ad bellum, and thus what is just is defined individually and subjectively. Schmitt, Carl. The Nomos of the Earth (New York: Telos Press, 2003), 143-147.

54 Martin, Cycle of Cathay 1900 (n. 31), 222.

55 Yang Zhuo 杨焯, Ding shi 'wanguo gongfa' yanjiu 《丁译“万国公法公法'研究》, (Hong Kong: The Hong Kong Polytechnic University, PhD Thesis, 2013), 18.

56 Li, Zhaojie (James). 'The Impact of International Law on the Transformation of China's Perception of the World: A Lesson from History'. Maryland Journal of International Law 27 (1) (2012), 128-153. 
Republica, binding upon the whole human race - which all mankind in all ages and countries, ancient and modern, savage and civilized, Christian and Pagan, have recognized in theory or in practice, have professed to obey, or have in fact obeyed. ${ }^{57}$ Martin's rendition of this paragraph, when retranslated literally, reads: 'Judging from them there is no universally practiced law as is said in Te-li [De Republica], for there has never been a case that is accepted by all nations at all times, barbarian or civilized, within or without the Church'. ${ }^{58} \mathrm{Hsu}$, Yang Zhuo, and Li show that such imprecise translations run through the book. ${ }^{59}$

Martin also saw the introduction of international law as good for China, and in New York Times articles written under the pseudonym 'Perry Plus', suggested that China's acceptance of Western diplomatic modes, such as the Burlingame mission, was not only positive for cooperation between the two countries but also a sign of China adopting liberal attitudes. ${ }^{60}$ His optimism and belief that China deserved better treatment from Western powers was opposed by Burlingame's successor, who claimed that Martin had 'materially contributed to the formation in the United States of an erroneous estimate of Chinese progress'.61 Overall, the general sentiment in the West was still quite negative toward China progress within international society.

\section{Ancient China's International Law: Expanding International Law's} Spatial and Temporal Dimensions

Martin aimed to make international law more acceptable to Chinese intellectuals, who were disillusioned about it. He also tried to help China become a member of international society when the West considered it to be at an eternal standstill and Western jurists were just starting to debate the idea of applying international law to the Orient. If Martin was supported by the Chinese Government, Burlingame, and Hart, and in a first moment international law was welcomed with interest by Chinese, there was also opposition from both the international community and within China. Wheaton's text itself suggests

57 Hsü, China's Entrance 196o (n. 2), 129; Wheaton, Henry. Elements of International Law (Lea and Blanchard, 1863), 17; Li, 'China's Perception of the World' 2012 (n. 56), 134.

58 Li, 'China's Perception of the World' 2012 (n. 56), 134; Martin, Wangguo Gongfa, 61; Hsü. China's Entrance 196o (n. 2), 129.

59 Hsü, China's Entrance 196o (n. 2), 129; Wheaton, Elements of International Law 1863 (n. 57), 17; Li, 'China's Perception of the World' 2012 (n. 56); Yang Zhuo 杨焯. Ding shi 'wanguo gongfa'yanjiu 《丁译'万国公法公法'研究》(Fal lü Chubanshe 法律出版社, 2015).

6o Martin, William A. P. 'The Chinese Embassy'. New York Times (18 February 1868), 1-2.

61 Covell, W. A. P. Martin 1978 (n. 34), 155 . 
that '[China] lacks certain attributes essential to regular and complete membership of the family of States, governed by, and enjoying the privileges of, the system of general international law. [... A]nd the refusal or inability of China to adopt the rules of war prescribed by the rules of civilized States for some time formed a grave if not an insuperable bar to her full recognition as a subject of international law. ${ }^{\prime} 2$ If Wheaton and others felt there were inescapable differences of civilization, some even opposed Martin attempting a translation. Michel Klecskowsky, the French charge d'affaires, said to Burlingame: 'Who is this man who is going to give the Chinese an insight into our European international law? Kill him - choke him off; he'll make us endless trouble. ${ }^{63}$ The US linguist, missionary and Sinologist Samuel Wells Williams believed that if China learned to understand how Western international law works, it would be able to justify the elimination of some aspects of the unequal treaties. ${ }^{64}$ Martin, who would become a member of the Institut de Droit International in 1882, was familiar with both the debates taking place among leading international jurists about the Oriental Question, and the general sentiments in the West about China. Despite his conflicting views, he saw China's past as characterized by constant transformation in political, intellectual and religious ideas and practices, which disproved the popular Western belief that China had been passive and immobile for millennia. ${ }^{65}$

Meanwhile, the Chinese court was still quite conservative and continue to see with suspicion Western techniques and learning, and Martin's translation was not warmly welcomed by the Zongli Yamen, which in theory should have been more open to Western ideas. A 1864 memorandum from Prince Gong and Zongli Yamen officials to the emperor explains that while Martin's effort to translate Western law was appreciated, he had been told that 'China has her own laws and institutions and that it is inconvenient to consult foreign books'. ${ }^{6}$ Martin was aware that international law was found suspect, 'as the Trojans did the gifts of the Greeks' ${ }^{67}$ While the first systematic translation of international law was received with some enthusiasm among Chinese

\footnotetext{
62 Wheaton, Henry and Coleman Phillipson. Wheaton's Elements of International Law (New York: Baker, Voorhis, $5^{\text {th }}$ ed. 1916).

63 Martin, Cycle of Cathay 1900 (n. 31), 234.

64 'Diplomatic Dispatches from China, XXII, S. Wells Williams to William Seward, November 23, 1865, in Presbyterian Church in the U.S.A. Board of Foreign Missions Correspondence and Reports, 1833-1911.

65 Martin, The Lore of Cathay 19o1, 2.

66 'Doc. 26 Prince Kung's Discovery of International Law', in Ssu-yü Têng, John K. Fairbank, et al, China's Response to the West: A Documentary Survey 1829-1923 (Cambridge: Harvard University Press, 1954), 98.

67 Martin, Cycle of Cathay 1900 (n. 31), 235.
} 
elites, ${ }^{68}$ the reality of power politics and the continuous encroachment of Qing territorial integrity by Western powers, which clearly considered China an outsider, disappointed them. ${ }^{69}$ International law, while increasingly necessary, was not enough to rescue China from its lowly international position. ${ }^{70}$

In response, in 1881 Martin elaborated the theory of the existence of international law in Ancient China. This could help convince the West that China was not uncivilized, and that it had many more similarities to the West than commonly believed. ${ }^{71}$ It could also encourage Chinese acceptance of a normative system and worldview that seemed completely foreign. Martin elaborated on his theory when invited to talk at the Congress of Orientalists in Berlin on September 13, 1881. A condensed outline of his paper, "Traces of International Law in Ancient China', was published in Congrès des Orientalists (no. 22, section 2, pp. $71-78$ ) in $1882 .{ }^{72}$ A Chinese version by Wang Fengzao was published by the Tongwen Guan as Zhongguo gushi gongfa lunlüe in 1884, and a Japanese version $1886 .{ }^{73}$ It was also translated into French for Revue de droit international (no. 14, pp. 227-242) in $1882 .{ }^{74}$ According to the paper presented in 1881:

68 See for instance Xiao Yonghong 萧永宏. 'Lun Yangwu shiqi Zhongguoren de guoji zhengzhi guannian 论洋务时期中国人的国际政治观念, Xueshu yuekan 学术月刊12 (1997), 86.

69 See Carrai, Sovereignty in China 2019 (n. 1), 66-73, 82-94.

70 Xiao Yonghong 萧永宏. 'Lun Yangwu shiqi Zhongguoren de guoji zhengzhi guannian 论 洋务时期中国人的国际政治观念, Xueshuyuekan 学术月刊12 (1997), 87 .

71 Annuaire de l'Institut de Droit International (Gand, etc., 1878), 105; 'Applicabilité du Droit des Gens Européen à la Chine. P. D. I. IX,' 387-401. Annuaire de l'Institut de droit international (Gand, 1879-80); see also 'Rapport on China and oriental Nations: Administration of Justice and Christianity missionaries'. Annuaire de l'Institut de Droit International (Gand, 1879-80), 301-303, 306. 'Mais, en général, dans nos rapports avec l'humanité non chrétienne, l'Europe ne voit que son intérêt. L'ailairo de l'opium (1) et plus encore la façon brutale dont la Russie a exterminé ou expulsé les tribus du Caucase, suilisent pour prouver l'infériorité du point de vue auquel se placent les Etats civilisés. Ils ont forcé la Chine à leur ouvrir sons ports : était-ce dans l'intérêt do la Chine? Tout ce qui se fait en Égypte est uniquement au profit des créanciers européens. Et dans la question meme qui nous occupe maintenant, à quoi pensons-nous surtout, sinon à sauvegarder les intérêts de nous nationaux?', ibid., 306 .

72 A revised version was published in the 'Traces of International Law in Ancient China', International Review 14(1), (1883), (63-77) in New York in January 1883 and reprinted in the Chinese Recorder (no. 14, 380-393) in Shanghai in September-October 1883. It was then further revised and included as 'International Law in Ancient China' in Martin's Hanlin Papers (second series, Chapter 5) in Shanghai in 1894 and in his The Lore of Cathay (Chapter 22) in New York in 1901.

73 Svarverud, International Law as World Order 2007 (n. 14), 100.

74 For further references to non-Chinese editions of Martin's paper, see Walker, Richard Louis. The Multi-State System of Ancient China (Westport: Greenwood Press, 1971), 129130; Covell, W. A. P. Martin 1978 (n. 34), 194 n. 85, 232. 
Chinese statesmen have pointed out the analogy of their own country at that epoch with the political division of modern Europe. In their own records they find usages, words and ideas corresponding to the terms of our modern international law, and they are by that fact the more disposed to accept the international code of Christendom, which it is no utopian vision to believe will one day become a bond of peace and justice between all the nations of the earth. ${ }^{75}$

Indeed, the idea relied on the analogy proposed by Xu Jiyu, as discussed above, and took up Martin's friend Zhang Sigui's original suggestion that there was an international law in Ancient China. Zhang had looked the preliminary version of Wanguo Gongfa and understood its relevance; his preface to the first edition suggests that the Warring States in many ways resembled the current European state system. ${ }^{76}$ Zhang's rationale was similar to that of Feng Guifen, also discussed above, and further developed Xu's analogy, but he analyzed the configuration of European countries in more detail: Russia would be Qin, Britain and France Chu and Jin, Austria and Prussia Lu and Wei, Turkey and Italy Song and Zheng, and so on. However, although it is obvious that he believed in China's superiority, it is interesting to note that Zhang did not directly compare the Qing to any other country. ${ }^{77}$ This no doubt reflected the influence of traditional thoughts in facing new problems. ${ }^{78}$

Martin's paper argues that during the period of chaos and disunity of the Warring States period, that was already considered by Xu Jiyu as the perfect analogy to better understand in Chinese terms the chaotic current

75 Martin, William A. P. 'Traces of International Law in Ancient China (1881)'. Chinese Recorder and Missionary Journal Vol. (13-14) (Charleston: Nabu Press, 2012), 393.

76 Martin, Cycle of Cathay 1900 (n. 31), 205.

77 “间尝观天下大局, 中华为首善之区, 四海会同, 万国来王。遐哉勿可及已。 此外诸国, 一春秋时大列国也，。。。在昔春秋之世，秦并歧丰之地，守关 中之险, 东面而临诸侯, 俄罗斯似之。楚国方城汉水, 虽众无用, 晋则表里 山河, 亦必无害, 英、法两国似之。齐表东海, 富甲天下, 美利坚似之。至 若奥地利、普鲁斯, 亦欧罗巴洲中两大国, 犹鲁、卫之政, 兄弟也。土耳 其、意大利, 犹宋与郑, 介与大国之间也。瑞士、比利时, 国小而固, 足以 自守。丹尼、荷兰、西班牙、葡萄牙等国, 昔为大国, 后渐陵夷, 然于会盟 友、征伐诸事, 亦能有 恃无恐, 而不至疲于奔命。其间蕞尔国, 不过如江、 黄、州、蓼, 降为附庸, 夷于邱县, 或割地而请和, 或要盟以结信, 不祀忽 诸, 可胜道哉” see Zhang Sigui's preface in Wheaton, Henry and W.A.P. Martin, Wan guo gong fa 《万国公法》 (Taibei: Zhongguo guo ji fa xue hui, 1998). Also discussed by Tian Tao 田涛, Guojifa shuru wanqing Zhongguo 《国际法输入与晚清中国》(Jinan: Jinan chubanshe, 2001), 55 .

78 Wang Ermin 王尔敏. Zhongguo Jindai sixiang shi lun xuji《中国近代思想史 论》 (Beijing: Shehui kexue wexian chuban, 2003), 97. 
international situation, the preconditions for international law existed: '1. The existence of a group of independent states, so situated as to require or favour the maintenance of friendly intercourse; 2 . That those states should be so related as to conduct their intercourse on a basis of equality.' ${ }^{79}$ The twelve Warring States developed a 'common code' that implied a basis of public law because it was recognized in times both of peace and war: a. In the conduct of war, the persons and property of non-combatants were required to be respected; $b$. In legitimate warfare, an enemy was not to be attacked without first sounding the drum and was to be given time to prepare for defence; c. A war was not to be undertaken without a decent pretext. d. A cause always recognized as just was the preservation of the balance of power; e. The right of existence was in general held sacred for the greater states which were held in fief from the imperial throne; $f$. The rights of neutrals were admitted, and to a certain extent respected. ${ }^{80}$ He concludes both Ancient Greece and China of the Spring and Autumn period had a rudimentary international legal code and that it is 'quite possible that text-books on the subject of international relations may have existed in ancient China, without coming down to our times, just as the Greeks had books on that subject, of which nothing now survives but their titles'. For Martin, when the Roman Empire disintegrated, the rudimentary Greek code developed into a practice of international intercourse between independent and equal states in Europe. His conclusion that China had an international code analogous to the Western system bolstered Chinese arguments that modern international law in the West had its antecedents in Ancient China. Yet Martin wrote that because the Chinese Empire disintegrated and was later re-established as a unified entity, a code of intercourse between equal, independent states based on a balance of power did not develop there. A tributary system of unequal and dependent states developed instead, and the Western legal model was only introduced through the Opium Wars and foreign trade on Chinese soil.

Martin saw that for a country like China with a long history and civilization and its own development logic, accepting the Western worldview and international law would not be an easy or natural process. The two defeats of the Opium Wars did not eradicate China's confidence in its civilization, and the Tongzhi Restoration of that same period involved a quest to find its own path for regaining strength through its own cultural and philosophical traditions. Chinese scholars and officials initially took a utilitarian attitude toward the Wanguo Gongfa as a mere tool for dealing with foreign powers; China was after

79 Martin, 'Traces of International Law' 2012 (n. 75), 64.

8o Ibid., $74-77$. 
all outside public law and superior to it. Investigating Ancient China helped show that principles of international law were not lacking in Chinese history, thus persuading China to accept international law as something that already existed and belonged to it, and was not foreign. ${ }^{81}$ One of Martin's purposes was thus to present the case that international law and diplomacy were not so much imposed on China by Europeans, as they were Chinese traditions resurrected for a new era; pre-Qing history was used to prove international law's universalism. ${ }^{82}$

Arguing for international law's existence in Ancient China reflected Martin's missionary flexibility, his idea that 'a good native pastor is indispensable to the prosperity of the little flock', 83 and his belief that Buddhism and Confucian ethics in particular could be related to Christian faith, preparing the soil for 'the cultivation of our Christian epoch. ${ }^{84}$ In the same way, China's past had prepared it for accepting Christianity and international law. His missionary approach was also reflected in the way he had preached international law in his very influential book Tiandao suyuan 天道溯源 (Evidences of Christianity), published in 1854 in China. ${ }^{85}$ This book extensively refers to traditional Chinese views as a starting point for the integration of Western Christianity. When Martin arrived in China, he became open to listening and learning from Chinese culture, such as the classics Book of Changes (or YiJing) and Spring and Autumn, borrowing concepts to spread Christianity from the traditional Chinese viewpoint. For example, he associated the goodness of Confucianism with the spirit of Jesus. This kind of thinking suffused his academic efforts throughout his life. The purpose of his research in Sinology was to promote mutual understanding between East and West, but a prerequisite for this understanding was that China join the family of the world's civilized countries. For this purpose, he believed that China must overcome its prejudice against the world. When translating international law, he adopted Evidences of Christianity to his newer mission.

81 Zeng Tao 曾涛, 'Jindai Zhongguo de guojifa fuhui lun 近代中国的国际法附会论' (2007).

82 Wang Hui王晖, Xiandai Zhongguo Sixiang de xingqi《现代中国思想的兴起》 (Beijing: Sheng huo du shu xin zhi san lian shu dian, 2008), 713.

83 'W. A. P. Martin, Shanghai, October 24, 1862', in Presbyterian Church in the U.S.A. Board of Foreign Missions Correspondence and Reports 1833-1911.

84 Martin, William A. P. 'Buddhism, A Preparation for Christianity'. Chinese Recorder (May, 1889), 193-203; Martin, William A. P. Hanlin Papers: Or Essays on the Intellectual Life of the Chinese (New York: Harper, 188o), 278-303; Martin, The Lore of Cathay 19o1, 249-63.

85 Martin, William A. P. Tiandao suyuan 《天道溯源》(Shanghai: Meihua shuguan, 1872). 
Martin's thesis has been criticized, and his arguments certainly contain flaws. ${ }^{86}$ For some scholars, the relationship between vassal states during the Zhou Dynasty was not equivalent to that between modern sovereign states, as the vassal state did not have the same international legal subjectivity. For the sake of universalizing international law, moreover, Martin abstracted the idea of modern nations so as to find them in the Confucian classics Zhou Li (Rites of Zhou) and Spring and Autumn Annals, thereby dismissing the historical context in which this idea emerged. Martin's strategy relativized the meaning of international law. ${ }^{87}$ It becomes a label defining the principles and laws governing relations between political entities in general. Martin forced it to become universal through a lack of historical accuracy, projecting into different times and spaces categories that were largely specific to European history. This was partly in opposition to the general view of jurists in Europe, for whom international law was a markedly European product; Martin was attempting to validate China's role in the history of a normative order that was until quite recently foreign to it - and initially imposed on it. The cost of this strategy appears to be a wholesale rewriting of history and a forceful imposition of Western categories onto China's complex history and pre-modern norms without questioning those categories, thus validating them and assuming them to be necessary. The idea, as pointed out by Wang Hui, was essentially to have the Chinese accept the legitimacy of European international law under the premise of its correspondence to universal principles, and then integrate China within the expanding Christian world order. ${ }^{88}$ Yet despite its flows, Martin's idea became extremely popular not only in China but in the US and Europe, and its legacy is still alive today.

86 Hao, Yen-p'ing and Erh-min Wang. 'Changing Chinese Views of Western Relations, 1840-95', in The Cambridge History of China, Volume 11 Part 2, eds. John K. Fairbank and Kwang-Ching Liu (Cambridge: Cambridge University Press, 1980), 142-201; Walker, The Multi-State System of Ancient China 1971 (n. 74).

87 See for example Hong Junpei 洪鈞培. Chun qiu guo ji gong fa《春秋國際公 法》(Shanghai, Zhonghua shu ju, 1939); Sun Yurong 孙玉荣. Gu dai Zhongguo guo ji fa yan jiu 《古代中国国际法研究》(Beijing Shi, Zhongguo zheng fa da xue chu ban she, 1999); Huai Xiaofeng and Sun Yurong 懷效鋒, 孫玉. Gu dai Zhongguo guo ji fa shi liao《古代中國國際法史料》(Beijing, Zhongguo zheng fa da xue chu ban she, 200o); Xu Chuanbao 徐傳寶, Xian Qin guo ji fa zhi yi ji《先秦國際法之遺跡》(Shanghai, Xu Chuanbao, 1931); Mu, He. 'The View of Early 2oth Century Chinese Intellectuals on Ancient China's International Law'. Peking University Law Journal 2(2) (2014), 487-517. Wang Hui. Xiandai Zhongguo Sixiang de xingqi《现代中国思想的兴起》. 


\section{Universalizing Confucianism through the History of International Law: A Chinese Response}

Martin might have not had much direct influence at the Institute du droit International, but after his 1881 presentation the idea that China had a system of interstate regulation resembling Western international law in the Zhou era, before 3 rd-century-BC unification, became a point of reference. In China many scholars started studying Ancient Chinese international law. ${ }^{89}$ The concept of "pre-Qing international law" flourished, and scholars directly compared international law with Spring and Autumn and Zhou Li; some compared Dutch jurist Hugo Grotius with Confucius. ${ }^{90}$ It had a huge impact on Chinese intellectuals and the jurists who studied under him, and contributed to the universalization of international law, becoming the basis for new Chinese foreign policy. It spread in Europe and the US and inspired several publications in Western languages and in Japanese. ${ }^{91}$

89 The results included Hu Weiyuan's 'Guide to Public Law' (1899), Liu Renxi's 'The Spring and Autumn Annals of the Spring and Autumn Law' (1911), and 'The Spring and Autumn Annals of the Public Law' (1912); Zhang Xinzheng's 'Spring and Autumn International Public Law' (1924); Xu Chuanbao's 'International Law and Ancient China, Part I: Thoughts' (1926); 'The Relics of Ancient China's International Law' (1931); Chen Guyuan's 'China's International Law Tracing' (1931), Ning Xiewan's 'Current International Law' (1933); Hong Yupei's 'Spring and Autumn International Public Law' (1937); Lei Haizong's 'Ancient Chinese Diplomacy' (1941); and Liu Bojun's 'Spring and Autumn League Politics' (1962). More recent works include Wang Tieya's speech at the Hague Academy of International Law, 'China and International Law - In History and Contemporary Times' (1990); Chen Shicai's 'The Source of Chinese International Law' (1994); Wang Tieya's 'Introduction to International Law' (1998); Sun Yurong's 'Ancient Chinese International Law Research' (1999); and Zhao Yanchang's 'Spring and Autumn Period International Law Research' (2004). For references see Zeng Tao 曾涛, 'Jindai Zhongguo de guojifa fuhui lun 近代 中国的国际法附会论' (2007). Many postgraduate theses by overseas Chinese students also discussed this issue, such as Xu Chuanbao and Hong Yupei, as well as Ma Derun, a doctoral thesis written by Ma Derun at the University of Berlin in Germany. Later, the paper was published in 1908 in Chinese by the Shanghai Commercial Press in the book 'China is in line with international public law.' He Bingsong wrote a master's thesis on 'Ancient Chinese International Law' in Princeton in 1916. In 1920, he published an article entitled 'Ancient Chinese International Law' in the Journal of Law and Politics, which was based on his master's thesis. See Zeng Tao 曾涛, 'Jindai Zhongguo de guojifa fuhui lun 近 代中国的国际法附会论' (2007).

90 Svarverud, International Law as World Order 2007 (n. 34).

91 Foreign literature that uses the analogy includes, inter alia, Cheng Yude's International Law of Early China (1927); Breton's 'Inter-State Relations of China before 700 AD' (1935); Frank Russell's Theories of International Relations (New York: AppletonCentury-Croft, 1936); Ku Shicai's 'National Equality of Ancient China' (1941); Kalevi Jaakko Holsti's, International Politics: A Framework for Analysis (Englewood Cliffs: 
As Rune Svarverud has noted, 'the very fact that an indigenous system of international law may be identified in these sacred writings, at the time of Confucius himself, and in the sacred tradition of the golden age of the ancient Zhou, has given these ideas high prestige in Confucian circles in China and in East Asia'. ${ }^{92}$ It served to create a sense of self-confidence for Chinese diplomats and intellectuals in international affairs, going well beyond Martin's intentions. While he thought that a system that worked well for China was useful as a way to find commensurability with international law and deserved study, he did not advocate export of Ancient Chinese legal institutions abroad. ${ }^{93}$ Chinese intellectuals, however, used Martin's idea not only to frame China's emerging international identity, but also to universalize Confucius in order to enlighten and correct the limits and hypocrisies of international law as translated from Western languages.

By the end of the 19th century, Chinese elites' acceptance of the framework of international law became a necessity. While even after the Second Opium War many conservatives at court saw international law as an instrument to handle inferior Western countries, the First Sino-Japanese War (1894-95) changed Chinese elites' self-understanding and permanently scattered the Chinese world order. Chinese scholar-officials had to reach a new understanding of themselves and their country's role in a world embracing international law, and emancipate themselves from the idea of Chinese civilization's uniqueness if they wanted to preserve their cultural traditions. ${ }^{94}$ Finding resources in Chinese tradition to understand the new reality facilitated this. The theory of international law's existence in Ancient China was adopted by many Chinese intellectuals and diplomats. ${ }^{95}$ For instance, in an 1884 article, the scholar and politician Liang Qichao (梁啟超) asked: 'Why should [we] have to be based upon a European book on international law for the principles of inter-state affairs?' ${ }^{\prime 6}$ Liang and other scholars looked into their own traditions,

Prentice-Hall, 1992); Sato Shinichi's Modern Chinese Intellectuals and Civilization (1996); Lydia H. Liu's The Clash of Empires (Cambridge: Harvard University Press, 2004); de la Brière, M. Yves. Le Droit des Gens et la Chine Antique (Paris: Librairie de Jurisprudence Ancienne et Moderne, 1926).

92 Svarverud, International Law as World Order 2007 (n. 34); Fu Deyuan 傅德元, Ding Weiliang yu jin dai Zhong xi wen hua jiao liu 丁韙良與近代中西文化交流 (Taibei Shi: Guo li Taiwan da xue chu ban zhong xin, 2013).

93 Covell, W. A. P. Martin 1978 (n. 34), 233.

94 Wang Hui 王晖, Xiandai Zhongguo Sixiang de xingqi《现代中国思想的兴起》, 726 .

95 These included Tang Caichang (唐才常), Feng Guifen (馮桂芬), Wang Tao (王瑶), Xue Fucheng (薛福成), Xu Keqin (許克勤), Zheng Guanying (鄭觀應), Ma Jianzhong (馬建 忠), Zeng Jize (曾紀澤), and Zhang Zhidong (張之洞).

96 Svarverud, International Law as World Order 2007 (n. 34), 6 o. 
in particular the Spring and Autumn period, to understand the contemporary international situation and find resources to confront it. In their description, England became Chu, France that of Qi, Germany became Jin, Russia became Qin, and the US the vassal Yan. Russia, given its increasing encroachment on Chinese territorial sovereignty, particularly in the northeast, was perceived as the greatest threat. The international society of the Spring and Autumn period, and the law regulating states then, was assimilated for analogy to the current state of international affairs and to the newly introduced gongfa, thus promoting its universalization in Chinese terms and broader acceptance in China.

Chinese scholar-officials were not simply trying to regain cultural confidence by demonstrating that international public law existed in China 2,000 years before the West. They knew that international law was being used by Western powers to justify gunboat diplomacy and encroachment of sovereignty. The introduction of social Darwinism in China in the 189 os and the country's critical situation at that time made Chinese intellectuals particularly aware of the empty morality of an international law that had forcefully opened the country to Western exploitation through the unequal treaties. Not only did they compare Confucian classics such as Spring and Autumn and Zhou Li to international law, but they also found in these texts authoritative justification for criticizing the essence of existing international relationships and attempting to reshape international law's spirit. Therefore, although many late Qing scholars and diplomats complained that China had various disadvantages outside of public international law and called on the country to accept this, they did not propose that China accept the legitimacy of a system that was the historical result of Western powers' interactions. In other words, the international law China accepted became an extension of Spring and Autumn and the law generated by the international relations of the Warring States period.

For instance, Zheng Guanying, a supporter of Western learning and international law, did not abandon the Chinese traditional worldview even when he conceived of China as a sovereign state. Zheng did recognize that there was no longer a central hemisphere in the globe which China occupied, and that 'all the countries are under the same heaven and on the same earth', but he believed China was the only country that truly followed the wangdao 王道, characterized by the primacy of morality (and opposed to the hegemonic badao 霸道). He felt this might one day spread among the barbarians, who would finally learn to respect the benevolence of which China was the ultimate embodiment. ${ }^{97} \mathrm{He}$ envisioned a world in which all religions would merge into Confucianism, and in which the Four Seas would be united in a central land, 
Zhongtu 中土. The intellectual Wang Tao also believed China would sooner or later re-acquire its imperial primacy. In his essay 'China's Enduring Superiority', he wrote that China was the historical embodiment of dao and that its superior civilization was a constant, while the West and its sovereign states system were doomed to destruction. ${ }^{98}$ For him the West's technology and international legal apparatus, including sovereignty, were simply instruments: 'they cannot be called the basis for governing the state and pacifying the world. The way of Confucius is the human way. As long as humankind exists, the way will remain unchanged'. This way was that of the three bonds and five relationships (the ruler to ruled, father to son, husband to wife, elder brother to younger brother, friend to friend) - that is, of hierarchy, not equality. ${ }^{99}$ International law and sovereignty were to be used temporarily in order to deal with foreigners, but soon the natural order of things would be restored. It is clear then that while Chinese scholars' arguments were similar to Martin's, their intentions were different. Martin was trying to universalize international law, clear the obstacles in the way Chinese acceptance of it, and promote China's recognition in international society among his colleagues at home. Late Qing Dynasty scholars, on the other hand, were attempting to create a new world order that, through reinterpretation of Confucian classics, embraced international law but through its Confucianization and the universalization of Chinese moral tradition.

After Chinese scholar-officials launched the reform movement in 1895, many intellectuals linked international law to the Spring and Autumn Period. Kang Youwei and Liang Qichao advocated for updating Confucius and made theoretical arguments for their political reforms. They interpreted history according to the Ancient Three Kingdoms (or Sanguo, used to refer to the period between $220-28 \mathrm{O} \mathrm{AD}$ and the trio of warring Chinese states that followed the fall of the Han dynasty (206 BC-AD 220), namely the Cao-Wei Empire 曹魏 (220-265), the Shu-Han Empire 蜀漢 (221-263) and the Wu Empire 吳 (222280)) and divided the human history into three periods: the chaotic world, the rising world, and the peaceful world, Taiping. Since human beings had not yet entered the Taiping, for Kang the international law that originated in the Spring and Autumn period had become the axiom of public justice in the world. ${ }^{100}$ For Liang and other intellectuals, if Grotius' work could be applied to competing nation-states of the Warring States Period as 'public law', then Spring and

98 Cohen, Paul A. 'Wang T'ao's Perspective on a Changing World', in Approaches to Modern Chinese History, eds. Rhoads Murphey and Mary C. Wright (Berkeley: University of California Press, 1967), 15-162.

99 Cohen, 'Wang T'ao's Perspective' 1967 (n. 98).

100 Kang Youwei 康有为, Kang Youwei Quanji, 《康有为全集》(Shanghai: Shanghai guji shudian, 1987), 574-575. Discussed in Zeng Tao, 'Jindai Zhongguo de guojifa fuhui lun'. 
Autumn could be used as the basic law of the new era of national competition, and Confucius' 'Great Harmony' thinking could be used as a universal law that goes beyond competition for power. ${ }^{101}$ Spring and Autumn international law could make up for the shortcomings of current international law. It was therefore imperative to not emphasize the uniqueness of the Chinese tradition, but to restructure a new world picture, using the internal context of Confucianism as a basis to establish a universalist worldview and public law. Without this kind of conceptual transformation, China would have to succumb to external rule. ${ }^{102}$

\section{Conclusion}

Politics of history continue to inform the historical constructions of international law. Normative reconstructions responding to contemporary necessities seem almost inescapable. This was the case in late-Qing China, where the histories of international law in Ancient China elaborated within one politics of history helped generate another: Martin, in keeping with his background, wanted to universalize international law as a way to bring about a 'Christian epoch', making it acceptable to the Chinese so that they would enter the family of civilized, Christian nations. Yet Chinese intellectuals took up Martin's idea not only to frame China's emerging international and sovereign identity, but also to universalize Confucius in order to use an autochthonous knowledge system to improve and reshape international law as translated from Western languages. By the 189os the theory of the Spring and Autumn and Warring States was consolidated and used as a framework for understanding the new international situation and the Qing empire within it. Yet through the end of the Qing Dynasty and during the Republic of China (1911-1949), as it became increasingly enmeshed within international law and foreign powers, an acceptance of international law became the starting point of China's diplomacy and emergence as an equal and then great power over the past century. The universal quest around Confucian texts lacked broader appeal and, crucially, China lacked the military or any other type of power to promote it universally. Unable to universalize Confucius, China's pursuit of equal status in the family

101 See Liang Qichao 梁启超, Liang Qichao quanji 《梁启超全集》 (Beijing: Beijing chubanshe 1999), 153-154.

102 Zeng Tao 曾涛 and Wang Hui 汪晖, Xiandai Zhongguo Sixiang de xingqi《现代中国思 想的兴起》, Vol. 1 (Hong Kong shudian, 2004), 726-727. 
of nations within the expanding Western international law system became the most realistic diplomatic choice - and an urgent one.

Nevertheless, the idea that Martin promoted, building on Chinese scholars' work, has continued to spark debates both within and outside China. In Japan, for instance, international law professor Keishiro Iriye wrote in 1967 that although there had been a system of quasi-sovereign equal states, a system of rituals characterized their relationships rather than international law. ${ }^{103}$ In China many republican scholars, such as Chen Guyuan and Zhou Gengsheng, did trace international law back to Confucius. ${ }^{104}$ Scholars like Wang Tieya and Xue Hanqin, although critical, have continued to rely on the idea that Ancient China had international law. ${ }^{105}$ A 1991 article titled 'China and International Law - In History and Contemporary Times' by Wang Tieya, one of China's most influential recent international law scholars, criticized Martin but did not dismiss the idea that the Ancient Chinese inter-state system was similar to that of Ancient Greece, and may have generated a proto-international law. ${ }^{106}$ More recently, legal historian Stephen Neff, in his Justice Among Nations: A History of International Law (2014), embraced Martin's idea. In attempting to write a global history of international law, Neff ascribes its origins to China's Warring States period, arguing that the first systematic writing of international relations occurred then, meaning international law's first appearance as an intellectual discipline. ${ }^{107}$ Just like Martin and many other scholars, especially in recent global histories of international law, in doing so Neff is required to force categories that are not necessarily universal into other histories. Ultimately, various Chinese scholars continue to use traditional resources to construct a

103 Iriye, Keishiro. "The Principles of International Law in the Light of Confucian Doctrine'. Recueil des Cours de l'Académie de Droit International de La Haye 120 (1967), 1-59.

104 Chen Guyuan 陈顾远, Zhongguo guojifa suyuan 《中国国际法溯源》 (Shanghai: Shanghai shu dian, 1991); Zhou Gengsheng 周鲠生, Guo ji fa 《國際法》[ International Law] (Beijing: Shang wu yin shu guan, 1976); Zhou Gengsheng 周鲠生, Guojifa dagang 《國際法大綱》 [A manual of international law] (Shanghai: Shangwu yinshuguan faxing, 1929).

105 Wang Tieya 王铁崖, Guojifa 《国际法》[International Law] (Beijing, Falü Chuban she, 1995); Wang Tieya. 'International Law in China: Historical and Contemporary Perspectives'. Recueil des Cours de l'Académie de Droit International de La Haye 221 (1990), 195-237; Xue, Hanqin. 'Chinese Contemporary Perspectives on International Law: History, Culture and International Law'. Recueil des Cours de l'Académie de Droit International de La Haye 355 (2011), 41-234.

106 Wang Tieya, 'Zhongguo yu guojifa - lishi yu dangdai' in Zhongguo guojifa niankan (Beijing: Zhongguo duiwai fanyi chubanshe, 1991), $5^{-115}$.

107 Neff, Stephen C. Justice among Nations. A History of International Law (Cambridge: Harvard University Press, 2014). 
vision of the Chinese world integrated within a universal one dominated by what was once Western international law, which has become in the course of the 2oth century a globalized reality. However, there are also Chinese scholars that have started to look once again at the normative history of China beyond international law, in support of the country great rejuvenation. If in the 19th century the universal quest around Confucian texts lacked broader appeal and China lacked the military or any other type of power to promote it universally, today the situation might be different.

\section{Acknowledgements}

This article was first presented at the Conference 'Politics and the Histories of International Law' organized at the Max Planck Institute for Comparative Public Law and International Law under the auspices of the Journal of the History of International Law on 16 February 2019. I am thankful to the American Presbyterian Society in Philadelphia for allowing me to use W. A. P. Martin's archival material and for the valuable comments of the reviewers and Dr. Stephen V. Crowder.

\section{Bibliography}

Anghie, Antony. Imperialism, Sovereignty and the Making of International Law (Cambridge: Cambridge University Press, 2005).

Burns, Norma J. W. A. P. Martin and the Westernization of China (Indiana University, M.A. Thesis, March 1954).

Carrai, Maria Adele. Sovereignty in China. A Genealogy of a Concept Since 1840 (Cambridge: Cambridge University Press, 2019).

Chiu, Hungdah. 'The Development of Chinese International Terms and the Problem of Their Translation into English.' Journal of Asian Studies 27(3) (1967), 485-501.

Cohen, Paul A. 'Wang T'ao's Perspective on a Changing World', in Approaches to Modern Chinese History, eds. Rhoads Murphey and Mary C. Wright (Berkeley: University of California Press, 1967), 158-162.

Covell, Ralph R. W. A. P. Martin, Pioneer of Progress in China (Christian University Press, 1978).

Deyuan, Fu 傅德元, Ding Weiliang yu jin dai Zhong xi wen hua jiao liu 《丁皘良與近代 中西文化交流》(Taibei Shi: Guo li Taiwan da xue chu ban zhong xin, 2013).

Ding, Weiliang 丁䞮良,Bangjiao Tiyao 《邦交提要》(廣學會清光緒三十年刻本, 1904). 
Drake, Fred. China Charts the World: Hsu Chi-Yu and His Geography of 1848 (Cambridge: Harvard University Press, 1975).

Fairbank, John K. and Ssu-yü Têng. China's Response to the West: A Documentary Survey 1839-1923, with E-Tu Zen Su, Chao Yingfang \& others, Cambridge, Mass.: Harvard University Press (New York: Athenum, 1965).

Fairbank, John K. and Ssu-yü Têng. 'On the Ch'ing Tributary System'. Harvard Journal of Asiatic Studies 6(2), 135-246.

Fairbank, John K., ed. The Chinese World Order, Traditional China's Foreign Relations (Cambridge: Harvard University Press, 1968).

Feng, Guifen 冯桂芬,Jiaobin lu Kangyi 《校邠庐抗议》, Volume 2, available at: https:// ctext.org/wiki.pl?if=gb\&res=551265\&searchu=\%E4\%BB $\% 8 \mathrm{~A} \% \mathrm{E} 6 \% \mathrm{~B}_{5} \% \mathrm{~B}_{7} \% \mathrm{E}_{5} \%$ A4\%96\&remap=gb (last accessed 14 September 2020).

Fu, Deyuan, 傅德元, 'Ding Weiliang wanguo gong fa fanyi lanben ji yitu xin tan 丁韪良 ‘万国公法’ 翻译蓝本及意图新探, Anhui Shixue 安徽史学 1 (2008), 45-53.

Guyuan, Chen 陈顾远, Zhongguo guojifa suyuan 《中国国际法溯源》 (Shanghai: Shanghai shu dian, 1991).

Hamashita, Takeshi. China, East Asia and the Global Economy: Regional and Historical Perspectives (Abingdon: Routledge, 2008).

Hao, Yen-p'ing and Erh-min Wang. 'Changing Chinese Views of Western relations, 1840-95', in The Cambridge History of China, Volume 11, Part 2, eds. John K. Fairbank and Kwang-Ching Liu (Cambridge: Cambridge University Press, 1980), 142-201.

Harris, Paul. 'Cultural Imperialism and American Protestant Missionaries: Collaboration and Dependency in Mid-Nineteenth-Century China'. Pacific Historical Review 6o(5) (1991), 309-338.

Hevia, James L. 'Sovereignty and Subject: Constituting Relationships of Power in Qing Guest Ritual', in Body, Subject and Power in China, eds. Angela Zito and Tani E. Barlow (Chicago: University of Chicago Press, 1994), 181-200.

Hong, Junpei 洪鈞培, Chun qiu guo ji gong fa 《春秋國際公法》 (Shanghai, Zhonghua shu ju, 1939).

Hsü, Immanuel C. China's Entrance into the Family of Nations: The Diplomatic Phase; 1858-1880 (Cambridge: Harvard University Press, 1968).

Huai, Xiaofeng and Sun Yurong 懷效鋒, 孫玉, Gu dai Zhongguo guo jifa shi liao 《古代 中國國際法史料》 (Beijing: Zhongguo zheng fa da xue chu ban she, 2000).

Iriye, Keishiro. 'The Principles of International Law in the Light of Confucian Doctrine'. Recueil des Cours de l'Académie de Droit International de La Haye 120 (1967), 1-59.

Kang, David C. East Asia Before the West: Five Centuries of Trade and Tribute (New York: Columbia University Press, 2010).

Kang, Youwei 康有为, Kang Youwei Quanji 《康有为全集》 (Shanghai: Shanghai guji shudian, 1987). 
Kennedy, David. 'International Law and the Nineteenth Century: History of an Illusion'. Nordic Journal of International Law 65 (1990), 385-420.

Koskenniemi, Martti. The Gentle Civilizer of Nations. The Rise and Fall of International Law 1870-1960 (Cambridge: Cambridge University Press, 2009).

Lam, Hok-Chung 林學忠, Cong wanguo gongfa dao gongfa waijiao 《從萬國公法到 公法外交》 [From the Law of Nations to International Diplomacy] (Shanghai: Shanghai Guji Chubanshe, 2009).

Latourette, Kenneth S. A History of Christian Missions in China (London: Society for Promoting Christian Knowledge, 1929).

Li, Zhaojie (James). 'The Impact of International Law on the Transformation of China's Perception of the World: A Lesson from History'. Maryland Journal of International Law 27(1) (2012), 128-153.

Liang, Qichao 梁启超, Liang Qichao quanji 《梁启超全集》 (Beijing: Beijing chubanshe 1999).

Lin, Zhiping 林治平, Kexue yu jiu en-Jidujiao yu huaren xiandaihua meijie renwu deyanjiu 《科學與救恩: 基督教與華人現代化媒介人物的研究》 (Taibei: Taibei Yuzhou guang chubanshe 1993).

Liu, Lydia. 'Legislating the Universal: The Circulation of International Law in the Nineteenth Century', in Tokens of Exchange: The Problem of Translation in Global Circulations, ed. Lydia Liu (Duke University Press, 1999), 127-164.

Liu, Lydia. The Clash of Empires: The Invention of China in Modern World Making (Cambridge: Harvard University Press, 2004).

Lutz, Jessie G. 'China's View of the West, A Comparison of the Historical Geographies of Wei Yuan and Xu Jiyu'. Social Sciences and Mission 25 (2012).

Macalister-Smith, Peter and Joachim Schwietzke. 'Bibliography of the Textbooks and Comprehensive Treaties in Positive International Law in the 19th Century'. Journal of the History of International Law 3(1) (2001), 75-142.

Mancall, Mark. China at the Center: 300 Years of Foreign Policy (New York: Free Press, 1984).

Martin, William A. P. A Cycle of Cathay: Or, China, South and North, with Personal Reminiscences (New York: Fleming H. Revell, 1900).

Martin, William A. P. 'Buddhism, A Preparation for Christianity'. Chinese Recorder (May, 1889), 193-203.

Martin, William A. P. Hanlin Papers: Or Essays on the Intellectual Life of the Chinese (London/New York: Trübner/Harper, 188o).

Martin, William A. P. Tiandao suyuan 《天道溯原》 (Shanghai: Meihua shuguan, 1872).

Martin, William A. P. The Awakening of China (New York: Doubleday, Page \& Company, 1910).

Martin, William A. P. 'The Chinese Embassy'. New York Times (18 February 1868), 1-2. 
Martin, William A. P. 'Traces of International Law in Ancient China' (1881). Chinese Recorder and Missionary Journal Vol. 13-14 (Nabu Press, 2012).

Martin, William A. P. Wan guo gong fa 《萬國公法》 (Taibei: Zhongguo guo ji fa xue hui, 1998).

Masini, Federico. The Formation of Modern Chinese Lexicon and its Evolution toward a National Language: The Period from 1840 to 1898 (Berkeley: Project on Linguistic Analysis, 1993).

Morse, H. B. The International Relations of the Chinese Empire, Vol. 3 (London: Longmans, Green \& Co., 1910).

$\mathrm{Mu}, \mathrm{He}$. 'The View of Early 2oth Century Chinese Intellectuals on Ancient China's International Law'. Peking University Law Journal 2(2) (2014), 487-517.

Neff, Stephen C. Justice among Nations. A History of International Law (Cambridge: Harvard University Press, 2014).

Nuzzo, Luigi. Origini di una Scienza. Diritto Internazionale e Colonialismo nel XIX secolo (Frankfurt am Main: Vittorio Klostermann, 2012).

Pines, Yuri. Envisioning Eternal Empire, Chinese Political Thought of the Warring States Era (Honolulu: University of Hawai'i Press, 2009).

Presbyterian Church in the U.S.A. Board of Foreign Missions Correspondence and Reports, 1833-1911.

Presbyterian Historical Society, Two American Embassies, I, 111, I, 32. CL IV, NINGBO, Martin to the Board, m. 86, May 22, 1859.

Renditions 53-54 (Spring and Autumn 2000).

Rossabi, Morris. China among Equals: The Middle Kingdom and its Neighbors (Berkeley: University of California Press, 1982).

Ruskola, Teemu. Legal Orientalism: China, the United States, and Modern Law (Cambridge: Harvard University Press, 2013).

Schmitt, Carl. The Nomos of the Earth (New York: Telos Press, 2003).

Schoppa, R. Keith. Revolution and Its Past: Identities and Change in Modern Chinese History (Upper Saddle River: Prentice Hall, 3rd ed., 2011).

Sebes, Joseph. The Jesuits and the Sino-Russian Treaty of Nerchinsk (1689): The Diary of Thomas Pereira (Rome: Institutum Historicum SI, 1961).

Sun, Yurong 孙玉荣, Gu dai Zhongguo guo ji fa yan jiu 《古代中国国际法研究》 (Beijing: Shi, Zhongguo zheng fa da xue chu ban she, 1999).

Suzuki, Shogo. Civilization and Empire: China and Japan's Encounter with European International Society (Abingdon: Routledge, 2009).

Svarverud, Rune. International Law as World Order in Late Imperial China: Translation, Reception and Discourse, 1847-1911 (Leiden: Brill, 2007).

The missionary review of the World (March 1917).

Tian, Tao 田涛, Guojifa shuru wanqing Zhongguo 《国际法输入与晚清中国》 (Jinan: Jinan chubanshe, 2001). 
Tian, Tao 田涛, 'Wan qing guojifa shu shu lun 晚清国际法输述论, Tianjin shehui kexue 天津社会科学 6 (1999), 99-103.

Treaty, Convention, etc. Between China and Foreign States, Vol. 1 \& 2 (Shanghai: Department of the Inspector General of the Customs, 1917).

Vec, Miloš. 'From the Congress of Vienna to the Paris Peace Treaties of 1919', in The Oxford Handbook of the History of International Law, eds. Bardo Fassbender and Anne Peters (Oxford: Oxford University Press, 2012), 654-678.

Vec, Miloš. 'Universalization, Particularization, and Discrimination. European Perspectives on a Cultural History of the 19th Century International Law'. InterDisciplines 3(2) (2012), 79-101.

Walker, Richard Louis. The Multi-State System of Ancient China (Westport: Greenwood Press, 1971).

Wang, Ermin 王尔敏, Zhongguo Jindai sixiang shi lun 《中国近代思想史论》 (Beijing: Shehui kexue wexian chuban, 2003).

Wang, Jing. 'The Image of China Shaped by American Missionaries and Its Impact on the Early Twentieth Century'. Journal of Cultural Interaction in East Asia 6 (2015), 31-45.

Wang, Dong. China's Unequal Treaties: Narrating National History (New York: Lexington Books, 2008).

Wang, Hui 王晖, Xiandai Zhongguo Sixiang de xingqi 《现代中国思想的兴起》 1 (Beijing: Sheng huo du shu xin zhi san lian shu dian, 2008).

Wang, Lixin 王立新, Meiguo Chanjiao shiyu wan qing zhongguo xiandaihua 《美国传 教士与晚清中国现代化》 (天津: 天津人民出版社, 1997).

Wang, Tieya 王铁崖, Guojifa 《国际法》 [International Law] (Beijing, Falü Chuban she, 1995).

Wang, Tieya. 'International Law in China: Historical and Contemporary Perspectives'. Recueil des Cours de l'Académie de Droit International de La Haye 221 (1990), 195-370.

Wang, Weijian 王维俭, 'Dingzheng ruogan zhongwai ci shu zhong Ding Weiliang ci mu sheji de shishi 订正若干中外词书中 '丁韪良” 词目涉及的史实” Zhongshan daxuebao 中山大学学报 2 (1987) 68-76.

Wang, Weijian 王维俭, 'Pu dan da zhan kou chuanbo shijian he xifang guojifa chuanru zhongguo 普丹大沾口船舶事件和西方国际法传入中国, Xueshuyanjiu 学术研究 5 (1985), 84-9o.

Wheaton, Henry. Elements of International Law (Lea and Blanchard, 1863).

Wheaton, Henry and Coleman Phillipson. Wheaton's Elements of International Law (New York: Baker, Voorhis, 5th ed., 1916).

Wheaton, Henry and William A. P. Martin. Wan guo gong fa 《万国公法》 (Taibei: Zhongguo guo ji fa xue hui, 1998).

Wright, David Curtis. From War to Diplomatic Parity in Eleventh-century China, Sung's Foreign Relations with Kitan Liao (Leiden: Brill, 2005). 
Wu, Suming 吴素敏, Ding Weiliang zhiyanjiu (1827-1916)《丁韪良之研究(1827-1916)》

(Taibei Donghai Daxue Zhuoshi lunwen, 1987).

Xiao, Yonghong 萧永宏, 'Lun Yangwu shiqi Zhongguoren de guoji zhengzhi guannian 论洋务时期中国人的国际政治观念, Xueshuyuekan 学术月刊 12 (1997), 83-9o.

$\mathrm{Xu}$, Chuanbao 徐傳寶, Xian Qin guojifa zhiyiji 《先秦國際法之遺跡》 (Shanghai: Xu Chuanbao, 1931).

Xue, Hanqin. 'Chinese Contemporary Perspectives on International Law: History, Culture and International Law'. Recueil des Cours de l'Académie de Droit International de La Haye 221 (1990), 41-234.

Yang, Zhuo 杨焯, Ding shi 'wanguo gongfa' yanjiu 《丁译 '万国公法公法' 研究》 (Falü Chubanshe 法律出版社, 2015).

Yang, Zhuo 杨焯, Ding shi 'wanguo gongfa' yanjiu 《丁译 '万国公法公法” 研究》, (Hong Kong: The Hong Kong Polytechnic University, PhD Dissertation 2013).

Zeng, Tao 曾涛, 'Jindai Zhongguo de guojifa fuhui lun 近代中国的国际法附会 论, Fashi xue kan 法史学刊 (2007), available at http://cesl.cupl.edu.cn/upload/ 201103224076o38.pdf.

Zeng, Tao 曾涛 and Wang Hui 汪晖, Xiandai Zhongguo Sixiang de xingqi 《现代中国思 想的兴起》, Vol. 1 (Sanlian shudian, 2004).

Zhang, Jingcao 张劲草, Qiu Zaijue 邱在珏, 'Lun guojifa zhi chuanru Zhongguo 论国际 法之传入中国, Hebei Daxue Xuebao 河北大学学报 2 (1984), 126-133.

Zhang, Weiming 张卫明, 'Yangwu shiqi guoren dui jindai guji jushi yu guojifa de bifu 洋务时期国人对近代国际局势与国际公法的比附, Shijie Jingji yu Zhengzhi世界经 济与政治 6 (2010): 81-83.

Zhou, Gengsheng 周鲠生, Guojifa dagang 《國際法大綱》 [A manual of international law] (Shanghai: Shangwu yinshuguan faxing, 1929).

Zhou, Gengsheng 周鲠生, Guojifa 《國際法》 [International Law] (Beijing: Shang wu yin shu guan, 1976). 